\title{
Pengaruh Jenis Mikoriza terhadap Pertumbuhan Beberapa Varietas Cabai pada Tanah Incepticol Krueng Raya Aceh Besar
}

\author{
The Effect of Mycorrhizal Types on the Growth of Some Chili Varieties in \\ Incepticol Soil Krueng Raya Aceh Besar
}

\author{
Rahmat Fitra Yandi Nasution ${ }^{1}$, Syamsuddin ${ }^{1}$, Syafruddin $^{1 *}$ \\ ${ }^{1}$ Program Studi Agroteknologi, Fakultas Pertanian, Universitas Syiah Kuala
}

\begin{abstract}
Abstrak. Penelitian ini bertujuan untuk mengetahui pengaruh jenis mikoriza, varietas dan interaksi jenis mikoriza dan varietas terhadap pertumbuhan dan hasil tanaman cabai pada tanah Incepticol. Penelitian ini dilaksanakan di Kebun Percobaan Iesuum Krueng Raya Aceh Besar, Rumah Kaca dan Laboratorium Fisiologi Tumbuhan Fakultas Pertanian Universitas Syiah Kuala Darussalam Banda Aceh dari bulan Mei sampai September 2018. Analisis data yang digunakan dalam penelitian ini adalah Rancangan Acak Kelompok (RAK) pola faktorial 3 x 2 dengan 3 ulangan. Faktor yang diamati dalam penelitian ini adalah jenis mikoriza dan varietas. Jenis mikoriza yang digunakan adalah Glomus mosseae, Gigaspora sp dan Campuran serta varietas yang digunakan adalah varietas Lado F1 dan Perintis. Hasil penelitian ini menunjukan jenis mikoriza berpengaruh nyata pada tinggi tanaman 30 dan 45 HSTdan jumlah cabang produktif. Jenis mikoriza terbaik terdapat pada jenis mikoriza campuran (Glomus mosseae dan Gigaspora sp). Pada varietas berpengaruh sangat nyata terhadap tinggi tanaman 15,30 dan 45 HST, diameter batang 30 dan 40 HST dan jumlah cabang produktif serta berpengaruh nyata pada diameter batang 45 HST. Jenis varietas terbaik terdapat pada varietas Lado. Interaksi antara jenis mikoriza dan jenis varietas berpengaruh sangat nyata terhadap tinggi tanaman 30 HST dan jumlah cabang produktif serta berpengaruh nyata pada diameter batang 30 HST.Interaksi antara jenis mikoriza dan varietas terbaik tedapat pada jenis mikoriza campuran (Glomus mosseae dan Gigaspora sp) dengan varietas Lado F1.
\end{abstract}

Kata kunci: Inceptisol, Jenis Mikoriza dan Varietas.

\begin{abstract}
This research aims to determine the effect of type of mycorrhiza, varieties, and interactions of mycorrhiza and varieties types on the growth and yield of chili plants on the Inceptisol land. This research was carried out at the Krueng Raya Iesuum Experimental Garden in Aceh Besar, greenhouse and laboratory of plant physiology, Faculty of Agriculture of Syiah Kuala University, Darussalam, Banda Aceh from Mei to September 2018. The analysis of data used in this study was Randomized Block Design -Factorial 3x2 with 3 replications. The factors observed in this research were the type of mycorrhiza and varieties. Types of mycorrhiza used are Glomus mosseae, Gigaspora, and the combination. Varieties used are Lado F1 and Perintis. The result of this research showed that types of mycorrhiza take effect significantly on plant height 30 dan 45 DAP and productive branch numbers. The mixed of mycorrhiza gives the best result on growth and yield of chili plant. The varieties of chili plants highly significant take effect on plant height 15, 30 and 45 DAP, stem diameter 30 and 40 HST and productive branch numbers and significantly affect on stem diameter 45 DAP. Lado F1 gives the best result on growth and yield. The interactions of mycorrhiza and varieties type highly significant take effect on plant height $30 \mathrm{HST}$ and productive branch number and significantly take effect on stem diameter $30 \mathrm{HST}$. The combination of mixed mycorrhiza and Lado F1 treatment gives the best result on growth and yield of chili plants.
\end{abstract}

Keyword : Inceptisol, types of mycorrhiza and varieties

\section{PENDAHULUAN}

Cabai (Capsicum annum L.) merupakan sayuran yang berasal dari Amerika yang sangat dibutuhkan masyarakat dalam jumlah besar sebagai bahan memasak, bahan baku industri seperti saus, bahan campuran balsem, permen, bahan obat- obatan dan lain-lain (Prajnanta, 2001). Cabai merupakan tanaman penting karena memiliki kandungan gizi yang tinggi, dalam $100 \mathrm{~g}$ cabai merah segar terdapat $31 \mathrm{~g}$ kalori, $1 \mathrm{~g}$ protein, 0,3 g lemak, 7,3 g 
karbohidrat, $29 \mathrm{mg}$ kalsium, $24 \mathrm{mg}$ fosfor, 0,4 g besi, 260SI vitamin A, 0,005 mg vitamin B1, $18 \mathrm{mg}$ vitamin C, dan 90,9 g air (Harwimuka, 2010). Oleh sebab itu ketersediaan cabai harus dipertahankan dengan cara meningkatkan produksi tanaman cabai.

Produktivitas cabai merah di Aceh cenderung fuktuatif, dilihat dari produktivitas cabai merah di Aceh pada tahun 2014 sebesar 10,37 ton ha ${ }^{-1}$ dan pada tahun 2015 terjadi kenaikan produktivitas sebesar 11,45 ton ha ${ }^{-1}$ tetapi pada tahun 2016 produktivitas cabai merah di Aceh menurun menjadi 10,64 ton ha $^{-1}$. Penurunan produktivitas cabai merah di Aceh pada tahun 2016 mencapai 7,08 \% dari tahun sebelumnya. Produktivitas cabai merah di Aceh sendiri masih tertinggal dari provinsi-provinsi lainnya di indonesia seperti Jawa Barat, dan Bali. Produktivitas cabai di aceh mengalami fluktuatif dikarenakan budidaya cabe merah yang kurang baik, salah satu penyebabnya adalah pemupukan dan penggunaan varietas (BPS, 2017).

Mikoriza memiliki potensi yang cukup besar dalam meningkatkan keberlanjutan ekosistem pertanian melalui peranannya dalam meningkatkan siklus nutrisi tanaman dan proses perbaikan agregat tanah. Adapun beberapa jenis-jenis mikoriza dalam penelitian ini yaitu Glomus mosseae, Gigaspora sp dan campuran. Menurut Penelitian Khodafi (2016), jenis mikoriza berpengaruh sangat nyata terhadap tinggi tanaman umur 15 HSPT dan 30 HSPT, berat buah, jumlah buah dan persentasi derajat infeksi akar, berpengaruh nyata terhadap diameter batang umur 15 HSPT, jumlah daun 15 HSPT dan 30 HSPT. Pertumbuhan dan hasil tanaman cabai yang terbaik dijumpai pada jenis mikoriza Gigaspora sp.

Varietas Lado F1 merupakan cabai hibrida yang dikembangkan oleh PT. East West Indonesia. Varietas cabai keriting Lado F1 sering disebut dengan keriting all season, karena varietas Lado F1 bisa dibudidayakan di segala musim serta berbagai ketinggian dengan agroklimat yang berbeda, bahkan varietas ini dapat tumbuh di pesisir yang panas. Tinggi tanaman varietas Lado F1 sekitar $100 \mathrm{~cm}$. Umur panen cabai varietas Lado F1 sekitar 90 HST. Warna buah muda yaitu hijau sedang sedangkan buah masak yaitu merah terang. Produktivitas varietas ini yaitu 0,9-1,4 kg/ tanaman. Varietas Lado F1 resisten terhadap penyakit layu bakteri, penyakit antraknosa, hama thrips dan bahkan masih mampu bisa berubah meskipun terserang virus Gemini (Syukur dan Maharijaya, 2014).

Varietas cabai Perintis merupakan varietas lokal yang dikembangkan di Desa Laweung Kabupaten Pidie Jaya. Varietas Perintis telah diuji secara teknologi, sehingga mampu berdaya hidup optimal dengan hasil yang maksimal, memiliki karakter sedikit lebih pendek dari jenis varietas cabai lain pada umumnya, tetapi tahan terhadap kutu daun dan juga serangan virus gemini yang menyebabkan tanaman cabai menjadi keriting. Cabai varietas perintis ini memiliki umur genjah 75-150 HST dan cocok untuk dibudidayakan di dataran rendah dan di dataran tinggi (Munawar, 2017).

Inceptisol merupakan ordo tanah yang belum berkembang lanjut dengan ciri-ciri bersolum tebal antara 1.5-10 meter di atas bahan induk, bereaksi masam dengan $\mathrm{pH}$ 4.5-6.5, bila mengalami perkembangan lebih lanjut $\mathrm{pH}$ naik menjadi kurang dari 5.0, dan kejenuhan basa dari rendah sampai sedang. Tekstur seluruh solum ini umumnya adalah liat, sedang strukturnya remah dan konsistensi adalah gembur. Secara umum, kesuburan dan sifat kimia Inceptisols relatif rendah, akan tetapi masih dapat diupayakan untuk ditingkatkan dengan penanganan dan teknologi yang tepat (Sudirja, 2007).

Faktor pembatas produksi tanaman yang tumbuh di tanah Inceptisol adalah kandungan unsur hara fosfor (P) dan kalium (K) yang masih dalam bentuk batuan belum mengalami pelapukan sehingga belum siap diserap oleh akar tanaman, tanah ini juga kekurangan unsur hara nitrogen. Tanah Inceptisol mempunyai nilai P-tersedia yang rendah (Damanik et al., 2010). Pemanfaatan cendawan mikoriza arbuskula (CMA) adalah salah satu alternatif untuk meningkatkan efisiensi pemupukan serta usaha perbaikan tanah Inceptisol. 
Cendawan mikoriza arbuskular memiliki dampak yang baik terhadap tanah, sehingga perlu untuk diterapkan dalam pengelolaan sistem pertanian berkelanjutan (Gianinazzi et al., 2010).

\section{METODOLOGI PENELITIAN}

\section{Waktu dan Tempat}

Penelitian ini dilaksanakan di Kebun Percobaan Iesuum Krueng Raya Aceh Besar, Rumah kaca dan Laboratorium Fisiologi Tumbuhan Fakultas Pertanian Universitas Syiah Kuala, Darussalam Banda Aceh. Penelitian berlangsung dari bulan Mei sampai September 2018.

\section{Alat dan Bahan}

Alat

Alat-alat yang digunakan dalam penelitian ini adalah cangkul, ayakan, garu, tali plastik, ajir, gunting, pisau, meteran, sendok, gembor, polibag, jangka sorong, timbangan digital, autoclave, plastik gula, kamera, mikroskop Nikon dengan pembesaran 100-400 kali, kaca preparat dan alat tulis.

\section{Bahan}

Bahan yang digunakan dalam penelitian ini adalah benih cabai varietas Lado F1 dan Perintis, pupuk hayati mikoriza jenis Glomus mosseae, Gigaspora sp dan Campuran, pupuk NPK, pupuk kandang, larutan KOH, aquades, dan larutan biru Ypan (Quick Parker).

\section{Analisis Data}

Penelitian ini dilaksanakan dengan menggunakan Rancangan Acak Kelompok (RAK) pola faktorial 3 x 2 dengan 3 kali ulangan. Adapun faktor yang diamati yaitu jenis mikoriza (M) dan faktor varietas (V). Faktor jenis mikoriza (M) terdiri dari 3 taraf yaitu Glomus mosseae, Gigaspora sp dan Campuran. Faktor varietas (V) terdiri dari 2 taraf yaitu varietas Lado F1 dan Perintis sehingga diperoleh 6 kombinasi perlakuan dan 18 satuan percobaan. Terdapat 2 seri dalam percobaan ini yaitu Seri A dan Seri B, seri A digunakan untuk pengambilan data pertumbuhan dan hasil tanaman cabai, sedangkan seri B digunakan untuk pengambilan data infeksi mikoriza.

\section{Pelaksanaan Penelitian}

\section{Perbanyakan Mikoriza}

Mikoriza yang digunakan pada penelitian ini yaitu mikoriza Glomus mosseae, Gigaspora sp, dan Campuran yang didapatkan dari hasil perbanyakan di rumah kaca Fakutas Pertanian Universitas Syiah Kuala.

Adapun metode yang dilakukan dalam pelaksanaan mikoriza yaitu :

1. Tanah diayak dengan menggunakan ayakan ukuran 9 mesh agar halus dan tidak tercampur dengan bebatuan kecil, setelah itu tanah dimasukkan kedalam kantong plastik yang tahan panas sebanyak 15 kantong plastik dengan volume $5 \mathrm{~kg}$.

2. Tanah disterilkan dengan autoclave pada suhu $121^{\circ} \mathrm{C}$ selama 30 menit dengan tujuan menghilangkan semua mikrooganisme yang didalam tanah baik yang menguntungkan maupun yang merugikan. 
3. Tanah yang sudah selesai di sterilkan dimasukkan ke pot yang telah dipersiapkan di rumah kaca sebagai media tanam. Tanaman inang yang digunakan untuk perbanayakan mikoriza adalah tanaman jagung.

4. Setelah tanah sudah selesai dimasukan di pot, dibuat lubang tanam dan dimasukkan starter mikoriza sebanyak 1 sendok per lubang tanam, setelah itu dimasukkan benih jagung 2 per lubang tanam kemudian ditutup dengan tanah.

5. Setelah tanaman berumur $45 \mathrm{HST}$, tanaman jagung diberikan perlakuan stressing (usaha menghambat atau menekan pertumbuhan tanaman inang dengan kondisi tertentu) dengan cara memotong daunnya dengan tujuan agar mikoriza bersimbiosis dengan akar tanaman jagung juga mengalami tekanan dan akan membentuk spora yang banyak pada akar tanaman jagung.

6. Setelah tanaman jagung mengalami proses stressing selama 1 bulan dan tanah menjadi kering, etelah itu dibongkar tanaman tersebut dan pada daerah akarnya digunting akarakar halusnya ukuran $1 \mathrm{~cm}$, selanjutnya akar tersebut dicampurkan dengan media zeolit.

7. Pupuk hayati mikoriza siap diaplikasikan pada tanaman cabai.

\section{Persiapan Lahan}

Lahan yang digunakan untuk penanaman cabai, terlebih dulu dilakukan pembersihan dengan mencabut gulma-gulma yang ada dilahan yang dapat menjadi inang hama dan penyakit, kemudian dilakukan pengolahan tanah dengan cara membajak atau mencangkul dengan kedalaman $30-40 \mathrm{~cm}$. Tanah yang selesai dicangkul kemudian dibiarkan selama 4 minggu agar terjadi pertukaran udara dan membunuh patogen-patogen merugikan yang ada didalam tanah. Setelah itu dilakukan pembuatan bedengan yang bertujuan untuk mencegah akar tanaman tidak tergenang pada saat musim hujan. Bedengan dibuat dengan lebar $1 \mathrm{~m}$, panjang $18 \mathrm{~m}$, tinggi $40 \mathrm{~cm}$, dan jarak antara bedengan dengan drainase $50 \mathrm{~cm}$.

\section{Pensiapan Benih}

Kriteria benih cabai yang digunakan yaitu benih yang terhindar dari serangan hama dan penyakit dan benih yang memiliki daya kecambah diatas $90 \%$. Didukung dengan adanya perlakuan perendaman dengan menggunakan aerator selama Kriteria benih cabai yang digunakan yaitu benih yang terhindar dari serangan hama dan penyakit dan benih yang memiliki daya kecambah diatas $90 \%$. Didukung dengan adanya perlakuan perendaman dengan menggunakan aerator selama 1-24 jam yang bertujuan untuk meningkatkan daya kecambah benih serta ketahanan benih terhadap serangan hama dan penyakit.

\section{Persiapan Pembibitan}

Benih yang digunakan dalam penelitian ini adalah benih cabai varietas Lado F1 dan Perintis. Benih disemai di polibag berukuran $5 \times 10 \mathrm{~cm}$ dengan media tanah inceptisol. Benih ditanam satu benih per polibag, kemudian diberikan perlakuan mikoriza sebanyak $5 \mathrm{~g}$ per polibag sesuai dengan jenis perlakuan mikoriza yang bertujuan agar tanaman cabai sudah mendapatkan rangsangan mikoriza saat pembibitan.

\section{Pemberian Pupuk Kandang}

Pupuk kandang diberikan dalam penelitian ini sebanyak $18 \mathrm{~kg}_{\text {bedeng }}{ }^{-1}$. Pemberian pupuk kandang bertujuan untuk meningkatkan nilai KPK (Kapasitas Pertukaran Kation) di dalam tanah sehingga hara tidak mudah hilang dan tercuci, memperbaiki struktur tanah, dan untuk meningkatkan daya menahan air sehingga air yang diserap lebih banyak.

\section{Pemberian Mulsa Plastik Hitam Perak (MPHP)}


Pemasangan mulsa plastahik hitam perak untuk menanam cabai dilakukan setelah bedengan selesai dipupuk. Pemasangan mulsa plastik hitam perak bertujuan untuk menekan pertumbuhan gulma, menjaga struktur tanah agar tetap baik , dan serta menjaga kelembaban tanah di bedengan.

\section{Penanaman dan Pemberian Mikoriza}

Jarak tanam yang digunakan dalam penelitian ini $60 \mathrm{~cm} \times 60 \mathrm{~cm}$. Pembuatan lubang tanam menggunakan sekop plastik dengan kedalaman $5 \mathrm{~cm}$. Penanaman dilakukan dengan pemberian mikoriza terlebih dahulu di lubang tanam yang telah disediakan sesuai dengan perlakuan (M1= Glomus mosseae, M2= Gigaspora sp, M3= Campuran) sebanyak $5 \mathrm{~g}$, selanjutnya bibit diletakkan pada lubang tanam kemudian ditutup dengan tanah. Penanaman cabai dilakukan pada sore hari. Bibit yang ditanam telah berumur 20 HST. Dipilih bibit yang pertumbuhannya baik dan sudah mempunyai 4-5 helai daun.

\section{Pemberian Pupuk NPK}

Pupuk NPK yang digunakan pada penelitian ini sebanyak $50 \%$ dari dosis anjuran yaitu 225 g bedeng $^{-1}$. Pupuk diberikan pada saat pindah tanam, 3 minggu setelah pindah tanam, dan 6 minggu setelah pindah tanam dengan cara melarutkan pupuk NPK dengan air lalu disiramkan pada area perakaran tanaman.

\section{Pemeliharaan}

Pemeliharaan tanaman cabai dilakukan setiap hari setelah tanam agar pertumbuhan tanaman cabai lebih baik. Pemeliharaan tanaman cabai yang dilakukan yaitu :

1. Penyulaman dilakukan pada saat tanaman cabai sebelum berumur 14 HST.

2. Penyiraman dilakukan $2 \times 1$ hari pada pagi dan sore hari.

3. Penyiangan dilakukan dengan membersihkan rumput-rumput yang berada disekitar bedengan.

4. Pembuangan tunas air dilakukan secara mekanis dengan menggunakan gunting pada umur 7-20 HST dan dilakukan 2 kali seminggu dengan tujuan merangsang pertumbuhan tanaman cabai agar tumbuh lebih baik.

5. Pemasangan ajir dilakukan setelah tanaman cabai 14 HST dengan menggunakan bahan dari kayu dengan tinggi $100 \mathrm{~cm}$ yang bertujuan untuk menopang tanaman cabai agar tidak mudah rebah.

6. Pengendalian hama dan penyakit dilakukan dengan penyemprotan menggunakan pestisida jika sudah menyerang lebih dari $20 \%$ populasi.

\section{Pemanenan}

Pemanenan cabai dilakukan pada umur 90, 95, 100, 105, 110, 115, dan 120 HST dengan kriteria cabai yang padat dan berwarna merah. Pemanenan dilakukan dengan cara memetik buah dengan tangkainya, bertujuan agar buah tetap segar dan tahan lebih lama ketika disimpan.

\section{Parameter Pengamatan}

\section{Tinggi Tanaman (cm)}

Pengukuran tinggi tanaman dilakukan pada saat tanaman berumur 15, 30, dan 45 HST. Pengukuran dilakukan mulai dari pangkal batang sampai titik tumbuh tertinggi tanaman dengan menggunakan meteran. 


\section{Diameter Batang (mm)}

Pengukuran diameter batang dilakukan pada saat tanaman berumur 30, 40, dan 45 HST. Pengukuran dilakukan dengan menggunakan jangka sorong pada bagian pangkal batang yang telah ditandai sebelumnya.

\section{Jumlah Cabang Produktif (cabang)}

Perhitungan jumlah cabang produktif dilakukan pada saat tanaman berumur 60 HST. Pengamatan jumlah cabang produktif dilakukan dengan menghitung jumlah cabang tanaman yang menghasilkan bunga dan buah.

\section{HASIL DAN PEMBAHASAN}

\section{Pengaruh Jenis Mikoriza terhadap Pertumbuhan Tanaman Cabai}

Hasil uji $\mathrm{F}$ menunjukan jenis mikoriza berpengaruh nyata pada tinggi tanaman 30 dan 45 HST dan jumlah cabang produktif.

Tabel 1. Rata-rata Pertumbuhan Tanaman Cabai akibat Jenis Mikoriza

\begin{tabular}{|c|c|c|c|c|}
\hline \multirow[b]{2}{*}{ Parameter } & \multicolumn{3}{|c|}{ Jenis Mikoriza } & \multirow[b]{2}{*}{$\mathrm{BNJ}_{0.05}$} \\
\hline & $\begin{array}{l}\text { Glomus mosseae } \\
\qquad\left(\mathrm{M}_{1}\right)\end{array}$ & $\begin{array}{c}\text { Gigaspora sp. } \\
\left(\mathrm{M}_{2}\right)\end{array}$ & $\begin{array}{c}\text { Campuran } \\
\left(\mathrm{M}_{3}\right)\end{array}$ & \\
\hline $\begin{array}{l}\text { Tinggi Tanaman } 30 \text { HST } \\
(\mathrm{cm})\end{array}$ & $53,57 \mathrm{a}$ & $55,17 a b$ & $57,13 b$ & 2,75 \\
\hline $\begin{array}{l}\text { Tinggi Tanaman } 45 \mathrm{HST} \\
(\mathrm{cm})\end{array}$ & $70,67 \mathrm{a}$ & $72,80 \mathrm{a}$ & $76,30 \mathrm{~b}$ & 3,10 \\
\hline $\begin{array}{l}\text { Jumlah Cabang Produktif } \\
\text { (Cabang) }\end{array}$ & $26 \mathrm{~b}$ & $24 \mathrm{a}$ & $26 \mathrm{~b}$ & 1,59 \\
\hline
\end{tabular}

Keterangan : Angka yang diikuti oleh huruf yang sama pada baris yang sama berbeda tidak nyata berdasarkan uji Beda Nyata Jujur (BNJ) pada taraf $\alpha=0,05$.

Tabel 1 menunjukan bahwa tinggi tanaman cabai umur 30 HST akibat perlakuan jenis mikoriza yang tertinggi dijumpai pada jenis campuran yaitu $57,13 \mathrm{~cm}$ yang berbeda nyata dengan mikoriza glomus mosseae. Pada tinggi tanaman cabai umur 45 HST akibat perlakuan jenis mikoriza yang tertinggi dijumpai pada jenis campuran yaitu $76,30 \mathrm{~cm}$ yang berbeda nyata dengan semua perlakuan. Pada jumlah cabang produktif akibat perlakuan jenis mikoriza yang terbanyak dijumpai pada jenis Glomus mosseae dan campuran yaitu 26 cabang yang berbeda nyata dengan Gigaspora sp.

Menurut Yusnizar et. al., (2006) bahwa pertumbuhan akar tanaman cabai yang diberikan pupuk hayati mikoriza Glomus mosseae dan Campuran cenderung lebih baik dibandingkan dengan jenis Gigaspora sp. Berdasarkan hasil penelitian Budianto (2016) menyatakan pertumbuhan dan hasil tanaman cabai terbaik dijumpai pada jenis mikoriza campuran berdasarkan parameter tinggi tanaman, jumlah daun, dan berat buah per tanaman.

Syafruddin et. al., (2012) dan Syafruddin et al, (2016) melaporkan bahwa mikoriza Campuran (Glomus dan Gigaspora) dan Glomus mosseae biasanya memiliki daya adaftasi dan pertumbuhan yang baik di daerah tercemar dan daerah tropis. Hal ini sesuai dengan 
penelitian dari Syamsiyah et al., (2012), yang menyatakan bahwa serapan hara $\mathrm{N}$ dan $\mathrm{P}$ yang tinggi terdapat pada tanaman yang diberi mikoriza, disebabkan mikoriza akan mendorong berkembangnya hifa pada akar tanaman.

\section{Pengaruh Varietas terhadap Pertumbuhan Tanaman Cabai}

Hasil uji $\mathrm{F}$ menunjukan varietas berpengaruh sangat nyata terhadap tinggi tanaman 15,30 dan 45 HST, diameter batang 30 dan 40 HST dan jumlah cabang produktif serta berpengaruh nyata pada diameter batang 45 HST.

Tabel 2. Rata-rata Pertumbuhan Tanaman Cabai akibat Varietas

\begin{tabular}{lccc}
\hline & \multicolumn{2}{c}{ Varietas } & \\
\cline { 2 - 3 } Parameter & Lado F1 & Perintis & BNJ $_{0.05}$ \\
\hline Tinggi Tanaman 15 HST (cm) & $36,84 \mathrm{~b}$ & $31,07 \mathrm{a}$ & 1,67 \\
Tinggi Tanaman 30 HST (cm) & $58,51 \mathrm{~b}$ & $52,07 \mathrm{a}$ & 1,83 \\
Tinggi Tanaman 45 HST (cm) & $77,64 \mathrm{~b}$ & $68,87 \mathrm{a}$ & 3,47 \\
Diameter Batang 30 HST (mm) & $6,79 \mathrm{~b}$ & $6,01 \mathrm{a}$ & 0,31 \\
Diameter Batang 40 HST (mm) & $7,99 \mathrm{~b}$ & $7,30 \mathrm{a}$ & 0,44 \\
Diameter Batang 45 HST (mm) & $8,79 \mathrm{~b}$ & $8,12 \mathrm{a}$ & 0,60 \\
Jumlah Cabang Produktif $(\mathrm{Cabang})$ & $28 \mathrm{~b}$ & $23 \mathrm{a}$ & 1,07 \\
\hline
\end{tabular}

Keterangan : Angka yang diikuti oleh huruf yang sama pada baris yang sama berbeda tidak nyata berdasarkan uji Beda Nyata Jujur (BNJ) pada taraf $\alpha=0,05$.

Tabel 2 menunjukan bahwa tinggi tanaman cabai umur 15,30 dan 45 HST akibat perlakuan varietas yang tertinggi dijumpai pada varietas Lado $F 1$ yaitu $36,84 \mathrm{~cm}, 58,51 \mathrm{~cm}$ dan 77,64 cm yang berbeda nyata dengan varietas Perintis. Pada diameter batang cabai umur 30,40 dan 45 HST akibat perlakuan varietas yang terbesar dijumpai pada varietas Lado F1 yaitu $6,79 \mathrm{~mm}, 7,99 \mathrm{~mm}$ dan $8,79 \mathrm{~mm}$ yang berbeda nyata dengan varietas Perintis. Pada jumlah cabang produktif akibat perlakuan varietas yang terbanyak dijumpai pada varietas Lado F1 yaitu 28 cabang yang berbeda nyata dengan varietas Perintis.

Varietas Lado F1 memiliki sifat yang lebih unggul, mampu beradaptasi dengan lingkungan hidupnya sehingga diharapkan dapat memberikan pertumbuhan dan hasil yang tinggi. Hal ini sejalan dengan pernyataan Prajnanta (2004) bahwa varietas unggul memiliki sifat keunggulan dari varietas lokal. Keunggulan tersebut dapat terlihat dari daya hasil buah pertanaman yang tinggi, respon terhadap pemupukan, serta resisten terhadap hama dan penyakit tanaman. Berdasarkan hasil penelitian Zubir (2017) bahwa perlakuan varietas berpengaruh sangat nyata terhadap tinggi tanaman, diameter batang dan jumlah panjang produktif.

\section{Interaksi Antara Jenis Mikoriza dengan Varietas terhadap Pertumbuhan Tanaman Cabai}

Rata-rata pertumbuhan tanaman cabai akibat interaksi antara jenis mikoriza dengan varietas cabai dapat dilihat pada Tabel 3. 
Tabel 3. Rata-rata pertumbuhan tanaman cabai akibat interaksi antara jenis mikoriza dengan varietas cabai

\begin{tabular}{|c|c|c|c|c|}
\hline \multirow[b]{2}{*}{ Parameter } & \multirow{2}{*}{$\begin{array}{c}\text { Jenis } \\
\text { Mikoriza }\end{array}$} & \multicolumn{2}{|c|}{ Varietas } & \multirow[b]{2}{*}{$\mathrm{BNJ}_{0.05}$} \\
\hline & & Lado F1 & Perintis & \\
\hline \multirow{3}{*}{ Tinggi Tanaman 30 HST $(\mathrm{cm})$} & Glomus mosseae & $53,93 \mathrm{Aa}$ & $53,20 \mathrm{Aa}$ & \\
\hline & Gigaspora sp. & $59,67 \mathrm{Bb}$ & $50,67 \mathrm{Aa}$ & 4,92 \\
\hline & Campuran & $61,93 \mathrm{Bb}$ & $52,33 \mathrm{Aa}$ & \\
\hline \multirow{3}{*}{ Diameter Batang 30 HST $(\mathrm{cm})$} & Glomus mosseae & $6,48 \mathrm{Aa}$ & $6,20 \mathrm{Aa}$ & \\
\hline & Gigaspora sp. & 6,68 Aa & 5,97 Aa & 0,88 \\
\hline & Campuran & $7,22 \mathrm{Ba}$ & $5,86 \mathrm{Aa}$ & \\
\hline \multirow{3}{*}{ Jumlah Cabang Produktif (cabang) } & Glomus mosseae & $27 \mathrm{Aa}$ & $26 \mathrm{Ab}$ & \\
\hline & Gigaspora sp. & $26 \mathrm{Ba}$ & $23 \mathrm{Aa}$ & 2,85 \\
\hline & Campuran & $31 \mathrm{Bb}$ & $21 \mathrm{Aa}$ & \\
\hline
\end{tabular}

Keterangan : Angka yang diikuti oleh huruf yang sama berbeda tidak nyata berdasarkan uji Beda Nyata Jujur (BNJ) pada taraf $\alpha=0,05$. Huruf kapital merupakan notasi pada baris, huruf kecil merupakan notasi pada kolom

Tabel 3 menunjukan bahwa tinggi tanaman cabai umur 30 HST yang tertinggi dijumpai pada kombinasi perlakuan jenis mikoriza campuran dengan Lado F1 yaitu $61,93 \mathrm{~cm}$ yang tidak berbeda nyata pada Gigaspora sp. dengan Lado F1 tetapi berbeda nyata dengan perlakuan lainnya. Pada diameter batang 30 HST yang terbesar dijumpai pada kombinasi perlakuan jenis mikoriza campuran dengan Lado $F 1$ yaitu $7,22 \mathrm{~mm}$ yang berbeda nyata dengan perlakuan lainnya. Pada jumlah cabang produktif yang terbanyak dijumpai pada kombinasi perlakuan jenis mikoriza campuran dengan Lado F1 yaitu 31 cabang yang berbeda nyata dengan perlakuan lainnya.

Varietas Lado F1 memiliki respon yang lebih baik terhadap pemberian mikoriza campuran. Hal ini didukung dengan pernyataan Sulistiyowati (2013), perbedaan reaksi antara mikoriza dengan tanaman sangat dipengaruhi oleh kepekaan tanaman terhadap infeksi dan sifat ketergantungan tanaman pada mikoriza dalam serapan hara.

Menurut Hayati et al., (2012), peningkatan produksi cabai dapat dilakukan dengan menggunakan varietas yang berdaya hasil tinggi, yang ditanam pada kondisi lingkungan yang sesuai dan didukung dengan penggunaan pupuk hayati salah satunya mikoriza. Hal ini didukung pernyataan Maryeni dan Heryani (2018) bahwa perkembangan dan kepadatan spora mikoriza secara positif berkorelasi dengan perkolonian akar, sehingga penyerpan unsur hara lebih baik dan akan mendukung pertumbuhan tanaman yang lebih baik. Menurut Sieverding (1991) menyatakan bahwa mikoriza yang menginfeksi sistem perakaran akan memproduksi jalinan hifa secara intensif sehingga akar tanaman yang bermikoriza akan mampu meningkatkan kapasitasnya dalam menyerap unsur hara dan air. Hal ini sejalan dengan pernyataan Fuady (2013) menyatakan mikoriza sangat berperan untuk meningkatkan serapan unsur hara, terutama unsur fosfat $(\mathrm{P})$. Mekanisme penyerapan unsur $\mathrm{P}$ dengan adanya kolonisasi mikoriza terjadi melalui hifa dalam tanah mengarbsopsi $\mathrm{P}$ dan mengangkutnya ke 
akar-akar yang dikolonisasi, dimana $\mathrm{P}$ ditransfer ke inang bermikoriza, sehingga meningkatnya volume tanah yang dapat dijangkau oleh sistem akar tanaman.

\section{SIMPULAN DAN SARAN}

Perlakuan jenis mikoriza berpengaruh nyata pada tinggi tanaman 30 dan 45 HST dan jumlah cabang produktif. Pertumbuhan tanaman cabai terbaik dijumpai pada jenis mikoriza campuran. Perlakuaan varietas berpengaruh sangat nyata pada tinggi tanaman 15, 30 dan 45 HST, diameter batang 30 dan 40 HST dan jumlah cabang produktif serta berpengaruh nyata pada diameter batang 45 HST. Pertumbuhan tanaman cabai terbaik dijumpai pada varietas Lado F1. Terdapat interaksi sangat nyata antara jenis mikoriza dengan varietas pada parameter tinggi tanaman 30 HST dan jumlah cabang produktif serta berinteraksi nyata terhadap diameter batang 30 HST.

Sehubungan dengan penelitian ini masih perlu dilakukan penelitian lebih lanjut mengenai penelitian perlakuan jenis mikoriza dan jenis varietas yang berbeda pada tanah Inceptisol untuk mendapatkan hasil tanaman cabai yang optimum.

\section{DAFTAR PUSTAKA}

Badan Pusat Statistik dan Direktorat Jenderal Hortikultura. 2017. Produktivitas Cabai Besar Menurut Provinsi 2012-2016. http://www.pertanian.go.id [14 Maret 2018]

Budianto, W. 2016. Pengaruh varietas dan jenis mikoriza terhadap pertumbuhan dan hasil cabai (Capsicum annum L.) pada tanah andisol. Skripsi. Program studi Agroteknologi, Universitas Syiah Kuala. Banda Aceh.

Damanik, M. M. B., Hasibuan, B. E., Sarifuddin., Fauzi., Hanum, H., 2010. Kesuburan Tanah dan Pemupukan. USU-Press, Medan.

Fuady, Z. 2013. Kontribusi cendawan mikoriza arbuskular terhadap pembentukan agregat tanah dan pertumbuhan tanaman. Lentera :Vol 13 No. 3, 2013 : 7-15.

Gianinazzi, S., A. Gollotte, M. N. Binet, D. van Tuinen, D. Redecker, and D. Wipf. 2010. Agroecology: The key role of arbuscular mycorrhizas in ecosystem services. Mycorrhiza. 20:519-530.

Harwimuka. 2010. Budidaya Cabai Merah. Insan Cendikia. Surabaya. 66 hlm.

Hayati, E, T. Mahmud, dan R. Fazil. 2012. Pengaruh jenis pupuk organik dan varietas terhadap pertumbuhan dan hasil tanaman cabai. Jurnal Floratek 7: 173-181.

Khodafi, A. Z. 2016. Pengaruh Jenis Mikoriza terhadap Pertumbuhan dan Hasil Beberapa Varietas Cabai pada Tanah Andisol. Skripsi. Program Studi Agroteknologi, Universitas Syiah Kuala. Banda Aceh.

Maryeni, R dan D. Hervani. 2008. Pengaruh mikoriza arbuskular terhadap pertumbuhan tanaman selasih (Ocinum sanctum L.). J. Akta Agrosia. 11(1): 7-12. 
Munawar, K. 2017. Cabe Perintis. [http://steemit.com/agriculture/@munawarkhalid/cabeperintis-a861f5bb1e3ab/] (tanggal 8 Mei 2018).

Prajnanta, F. 2004. Pemeliharaan Tanaman Budidaya Secara Intensif dan Kiat Sukses Beragribisnis. Penebar Swadaya. Bogor.

Sieverding, E. 1991. Vesicular Arbuskular Mychorhiza Management in Tropical Agrosystem. Eschbom: Deutsche GHTZ Gmbh.

Sudirja R. 2007. Respons beberapa sifat kimia inceptisol asal rajamandala dan hasil bibit Kakao melalui pemberian pupuk organik dan pupuk hayati. lembaga penelitian Universitas Padjadjaran. Bandung.

Sulistiyowati, 2013. Kompatibilitas tanaman tomat dan cabai dengan kombinasi pupuk organik dan hayati (cendawan mikoriza arbuskular). Fakultas keguruan dan ilmu pendidikan. Universitas muhammadiyah. Surakarta.

Syukur, M dan A. Maharijaya. 2014. Menghasilkan Cabai Keriting Kualitas Premium. Penebar Swadaya. Jakarta.

Syafruddin and Efendi. 2012. Effect of provisioning bacterial isolates and NP fertilization on total microorganism and degradation level contaminated Inceptisol soil. Int. J. Agric. Res., 7 : 449-456

Syafruddin S., S, Syakur and T, Arabia. 2016. Propagation techniques of mycorrhizal biofertiliser with different types of mycorrhizal inoculant and host plant in Entisol Aceh. Int. J.Agric. Res, 11 (2) : $69-76$

Syamsiyah, J., Bambang, H. S., Eko, H dan Jaka, W. 2012. pengaruh inokulasi jamur mikoriza arbuskula terhadap glomalin, pertumbuhan dan hasil padi. Jurnal. Fakultas Pertanian. Universitas Gajah Mada. Yogyakarta.

Yusnizar, Hifnalisa, dan Fikrinda. 2006. Populasi dan aktivitas mikroorganisme rhizosfer kedelai pada entisol akibat pemberian bahan organik dan pupuk hayati. Agrista. 52 : 1410-3389.

Zubir, M. 2017. Pengaruh Dosis Mikoriza Campuran (Glomus mosseae dan Gigaspora sp.) Terhadap Pertumbuhan dan Hasil Beberapa Varietas Cabai (Capsicum annum L.) Pada Tanah Andisol Burni Telong Kabupaten Bener Meriah. Skripsi. Program Studi Agroteknologi, Universitas Syiah Kuala. Banda Aceh. 